\title{
How Far Can You Go with Your Studies at UNED?
}

\author{
Cristina Gutiérrez-Carranza* \\ https://orcid.org/0000-0002-2965-1910
}

Recibido: 12 de febrero de 2020 • Aceptado: 19 de marzo de 2020

\begin{abstract}
The State University of Distance Education (UNED, Universidad Estatal a Distancia) has always made efforts to be at the forefront of advancement and opportunities for its students. These efforts have taken this home of learning to international levels and guided this institution to increase its standards of quality formation for its students.

This article demonstrates how the chance to develop a technology-related idea resulted in the participation in an internship at Savonia University of Applied Science (UAS) in Kuopio, Finland. Additionally, this internship aided in the immersion in follow up events that contributed to the professional growth of a student from the major of Sustainable Tourism Management. This article briefly explains the tasks assigned in two courses taken at Savonia University of Applied Science (UAS). It also narrates student life at this university. Finally, it explains how far nationally and internationally students at UNED can go if they pursuit educational goals, take advantage of UNED's partnerships, and exert all efforts.
\end{abstract}

Key words: Tourism, design thinking, Finland, internship, technology.

\footnotetext{
* Bachiller en la enseñanza del inglés de la Universidad de Costa Rica (UCR), de Costa Rica. Licenciada en Lengua inglesa de la UCR. Máster en Enseñanza del inglés de la Universidad Latina de Costa Rica. Bachiller en Gestión Turística Sostenible de la Universidad Estatal a Distancia (UNED). Instructora de inglés en el Instituto Nacional de Aprendizaje en la Unidad Regional Huetar Norte. Correo: cristina.gutierrez@uned.cr
} 


\section{¿Qué tan lejos puede llegar usted con sus estudios en la UNED?}

\section{Resumen}

La Universidad Estatal a Distancia (UNED) siempre ha realizado esfuerzos para estar a la vanguardia del avance y de oportunidades para sus estudiantes. Estas labores han llevado a esta casa de aprendizaje a niveles internacionales y han guiado a esta institución a elevar sus estándares de formación de calidad para sus estudiantes.

Este artículo demuestra cómo la oportunidad de desarrollar una idea relacionada con tecnología, resultó en la participación en una pasantía en la Universidad de Ciencias Aplicadadas de Savonia (UAS), en Kuopio, Finlandia. Aunado a esto, esta pasantía ayudó a la inmersión en otros eventos de seguimiento que contribuyeron al crecimiento profesional de una estudiante de la carrera Gestión y Gerencia del Turismo Sostenible. Este texto explica brevemente las tareas asignadas en dos cursos llevados en la UAS. Además, explica cómo es la vida estudiantil en esta universidad. Finalmente, narra qué tan lejos pueden llegar los estudiantes de la UNED, tanto nacional como internacionalmente, si persiguen sus objetivos, toman ventaja de las alianzas con las que cuenta la UNED y realizan grandes esfuerzos.

Palabras clave: Turismo, design thinking, Finlandia, pasantía, tecnología.

\section{Jusqu'où pouvez-vous aller si vous étudiez à l'UNED?}

\section{Résumé}

L'Université de l'État à Distance (UNED) a toujours fait des efforts pour être à la pointe de l'avant-garde des opportunités pour ses étudiants. Ces efforts ont mené cette institution au niveau international et l'ont guidée à élever les standards de qualité de la formation de ses étudiants.

Cet article démontre comment l'opportunité de développer une idée rapportée à la technologie a permis la participation dans un stage à l'Université de sciences appliquées Savonia (UAS) à Kupio, Finlande. À cet égard, le stage a contribué à l'immersion dans d'autres événements de suivi qui ont aidé au développement professionnel d'une étudiante de la filière de Gestion et administration du tourisme durable. Ce texte explique brièvement les tâches assignées en deux cours à l'UAS, et la vie étudiante dans cette université. Finalement, l'article raconte jusqu'où peuvent aller les étudiants de l'UNED au niveau national et international, s'ils poursuivent leurs buts, profitent des avantages des partenariats qui possède l'UNED, et s'ils font des gros efforts.

Mots-clés: Tourisme, desing thinking, Finlande, stage, technologie. 


\section{Introduction}

Even though technology is becoming increasingly more prevalent, some people are still afraid to confront the latest versions of it. Due to this reluctance to recent changes, a lot of people have failed to take the challenge of making their lives easier by using technology. This does not mean every person has to be an expert in the breakthroughs coming out every minute, but at least, it is important to accept and adapt to the useful advancements around humankind.

The State University of Distance Education in Costa Rica, UNED, has taken on the task of enrolling students in courses and programs that will help them deal with technology. Strategically, this institution has incorporated new investigation methods like Design Thinking in its curricula. Teaching students about this matter provides them with tools to solve problems focusing on users and how to meet their needs and expectations. This way, when UNED students run into conflict at different moments in life, they can solve them a lot more efficiently.

Along with these efforts made by UNED to work more on Information Technology (IT) and Design Thinking related areas, UNED has also worked on making international connections with prestigious institutions like Savonia University of Applied Science (UAS) in Kuopio, Finland.

This alliance is quite strategical since a country like Finland is a strong model in terms of its exemplary educational system. Furthermore, the two institutions found several points of common ground; for example, their majors related to tourism and business administration and the incorporation of Design Thinking in their curricula.

As a result of this cooperation and resolutions from UNED, the internship explained in this article came to fruition. Along with it, all the follow-up activities linked to it have been quite motivational to go on working hard. The fulfillment of these activities has proved how worthy it could be to get involved in unknown fields with guidance of professionals and UNED's support.

\section{The beginnings}

In addition to being the pioneer institution of distance education in Costa Rica, UNED (Universidad Estatal a Distancia) has also made efforts to keep innovation as one of its strengths. Therefore, the incorporation of technology in its research and study methodologies is an everyday target for UNED.

Recently, one of the strategies UNED has put into practice to achieve this objective is the inclusion of a new research method called Design Thinking.

In the case of the School of Social Sciences and Human Studies, this new investigation trend was introduced as an opportunity for innovation. In this scenario, students were given the chance to come up with a product idea they could develop using the Design thinking methodology. So, instead of taking one of the regular subjects in the study plan, in 2017, five students from the Sustainable Tourism Management major decided to take the challenge of enrolling in this Design Thinking course. 


\section{Design thinking}

Recently, Design thinking has become a very popular problem-solving methodology. A lot of literature has been developed about it, that is why there are many definitions available. However, a very accurate definition is presented by Stevens:

Design Thinking is an approach used for practical and creative problem-solving. It is based heavily on the methods and processes that designers use (hence the name), but it has actually evolved from a range of different fields -including architecture, engineering, and business. Design Thinking can also be applied to any field; it doesn't necessarily have to be design-specific. Design Thinking is extremely user-centric. It focuses on humans first and foremost, seeking to understand people's needs and come up with effective solutions to meet those needs. It is what we call a solution-based approach to problem-solving ${ }^{1}$.

In the field of tourism, there are endless ways to put Design Thinking into practice, mainly because there is a lot of customer service in its different areas. For a touristic service to be successful, it is primordial to create empathy with the client, and interestingly establishing this type of rapport is one of the principles of Design Thinking. Furthermore, in tourism, the fields of innovation and technological breakthroughs are imminent. On the same matter, problem-solving is an aspect present in everyday tourism environments, where Design Thinking can play a significant role.

The way design thinking was implemented in the project exposed in this article was by attempting to make tasks easier for tour guides. This would be done by creating a bracelet that would help tour guides monitor their clients' location, heart rate, temperature, and assistance needed. The support for prototyping this idea in its beginning stages was provided by the Fab Lab «Ka träre».

\section{Fab Lab «Ka träre»}

The Fab Lab at UNED was born in 2014. Its purpose is to give an answer to the innovation need in academic scenarios and research. Additionally, it provides access to open technologies to all the students and collaborators at UNED. People who are interested in prototyping and technology can have access to this space ${ }^{2}$.

For elaborating the prototype of the bracelet, it was necessary to do research on how the device could be created. In the Fab Lab «Ka träre», students can count with the help of professionals in different technological areas. For example, Ana María Sandoval Poveda who is a mathematician, Esterlyn Quesada Brenes, a programming engineer, Farith Tabash Pérez, an industrial engineer, Esteban Campos Zumbado, audiovisuals expert, Diana Hernandez Montoya, the person in charge of the

\footnotetext{
${ }^{1}$ Emily Stevens, «Career foundry. What Is Design Thinking? A Comprehensive Beginner's Guide», accessed on May 16, 2019, https://careerfoundry.com/en/blog/ux-design/what-isdesign-thinking-everything-you-need-to-know-to-get-started/

${ }^{2}$ Sandoval, Ana-María, Observatorio de tecnología en educación a distancia (2018), accessed on March 02, 2019, https://observatoriotecedu.uned.ac.cr/laboratorio-fabricacionfab-lab-ka-trare/
} 
laboratory, among other professionals who have established a friendly lab environment to materialize creative and innovative ideas.

The work students can do in the Fab Lab «Ka träre» perfectly matches the Design Thinking methodology since participants can develop their ideas, create prototypes, and test them as they move ahead or backwards in the different stages of the process.

Furthermore, the work students do in the Fab Lab «Ka träre» has external projection and impact working as a catalyst that transforms the knowledge acquired and developed in the laboratory, into entrepreneurship projects, research opportunities, job positions, and even internships abroad, which is the case of this project. Thanks to the Students' Academic International Mobility Department, this project was suitable to be followed up in Savonia University of Applied Science (UAS) in Kuopio, Finland.

\section{Students’ Academic International Mobility Department}

This department offers students the opportunity to participate in academic experiences in countries abroad.

International mobility represents an alternative to increase the academic quality and the international competitiveness of students. It promotes diversity and strengthens intercultural understanding. Furthermore, this department enriches the intellectual aspects of the students. Finally, students can expand their horizons since these international experiences ease their knowledge transference and enhance their curriculum vitae ${ }^{3}$.

The internship this article refers to took place thanks to the contribution of this department and the connection that had already been made with Savonia University of Applied Sciences in Kuopio, Finland.

Firstly, BEng. Oscar Romero Cruz, in charge of the Business Administration and Production program at UNED, visited this university in Finland in 2016. After that, in 2017, MSSc Paola Kontro, the International Coordinator in the School of Business and Tourism \& Hospitality from UAS in Kuopio, Finland, visited UNED in Costa Rica. Later, MSc. Ileana Garita González, the Coordinator of the Sustainable Tourism Management Program, in February 2018 visited UAS as well.

After all of these and some other approaches, agreements and constant communication with UAS, Cristina Gutiérrez Carranza's internship was suggested by Mag. Susan Solís Rosales, the person in charge of the Sustainable Tourism Chair, and MSc Garita González.

The process required constant communication, coordination, and guidance from all the parts involved. After several months of hard work and requirements to be fulfilled, on September $22^{\text {nd }}, 2018$ this amazing dream came true.

\footnotetext{
${ }^{3}$ Movilidad Estudiantil, 2019. 


\section{Savonia University of Applied Sciences (UAS) in Kuopio, Finland}

Savonia University of Applied Sciences is one of the largest and most versatile Universities of Applied Sciences in Finland. Its organization of experts educates strong professionals in six different fields of study. Its versatile Degree Programs offer the students the opportunity to study as a fulltime student, alongside their job (Master's Degree and specialized studies) or flexibly in the Open University of Applied Sciences. There are campuses in Kuopio, Iisalmi, and Varkaus.

Savonia UAS is profiled by its focus areas. Each focus area contains both basic and higher university of applied sciences education, diverse Research Development and Innovation (RDI) activities and strong business activities. The focus area activities are significant and acknowledged both nationally and internationally.

As Savonia UAS is a multidisciplinary university of applied sciences, naturally, it has high-quality core mission-based activities outside of the focus areas. The selected focus areas are Applied Wellbeing Technology, Innovative Engineering and Energy Industries, Responsible Food Production, and Water Safety. The unifying theme in these disciplines is digital solutions. The philosophy of the focus areas is built on product development, creative experiments, entrepreneurship, innovations, business expertise, and internationality ${ }^{4}$.

The Finnish educational system is considered exemplary around the world. That is why UNED made a very accurate choice on creating links between the two universities. Hopefully, the partnership between these two institutions will continue to be fruitful and bring more opportunities for the personnel and students to further exchange academic experiences.

\section{The internship}

This experience is highly recommended for students who want to take risks and walk the extra mile. The chance to study at such a prestigious university was definitely unforgettable and valuable. Seeing firsthand how higher education works in a first world country brings a great deal of significance to any professional's life.

Even though the time actually spent in Savonia UAS was only two weeks, the academic activities started in August 2018. For one semester, there was an opportunity to take two online courses in which the proposal started at UNED about the creation of the bracelet would be followed up. The semester was supposed to take from August 2018 to January 2019. However, due to the modality in which the online courses were taken, the enrollment was limited to finish in December 2018.

\section{Life as a student at Savonia UAS}

Months before their arrival at Savonia University, students are provided with all the details about their stay in Finland. A very useful idea they put into practice is assigning to the visitors academic and personal tutors who do volunteer work. These volunteers accompany the newcomers and support them in terms of life and school in Finland, they also guide the students on cultural activities, places to visit in town, and in general, tips for living in Kuopio. The academic tutor would help the guest

${ }^{4}$ Savonia University of Applied Sciences, 2019.

ESPIGA] @(1)(2) Año 20, N. ${ }^{\text {o }}$ 40: 173-190, julio - diciembre 2020 
students with student services, libraries, laboratories, classroom arrangements, schedules, and the use of the university software.

In this opportunity the tutors were Outi Vilpponen and Veera Kinnunenwho who study Tourism and Hospitality at Savonia UAS.

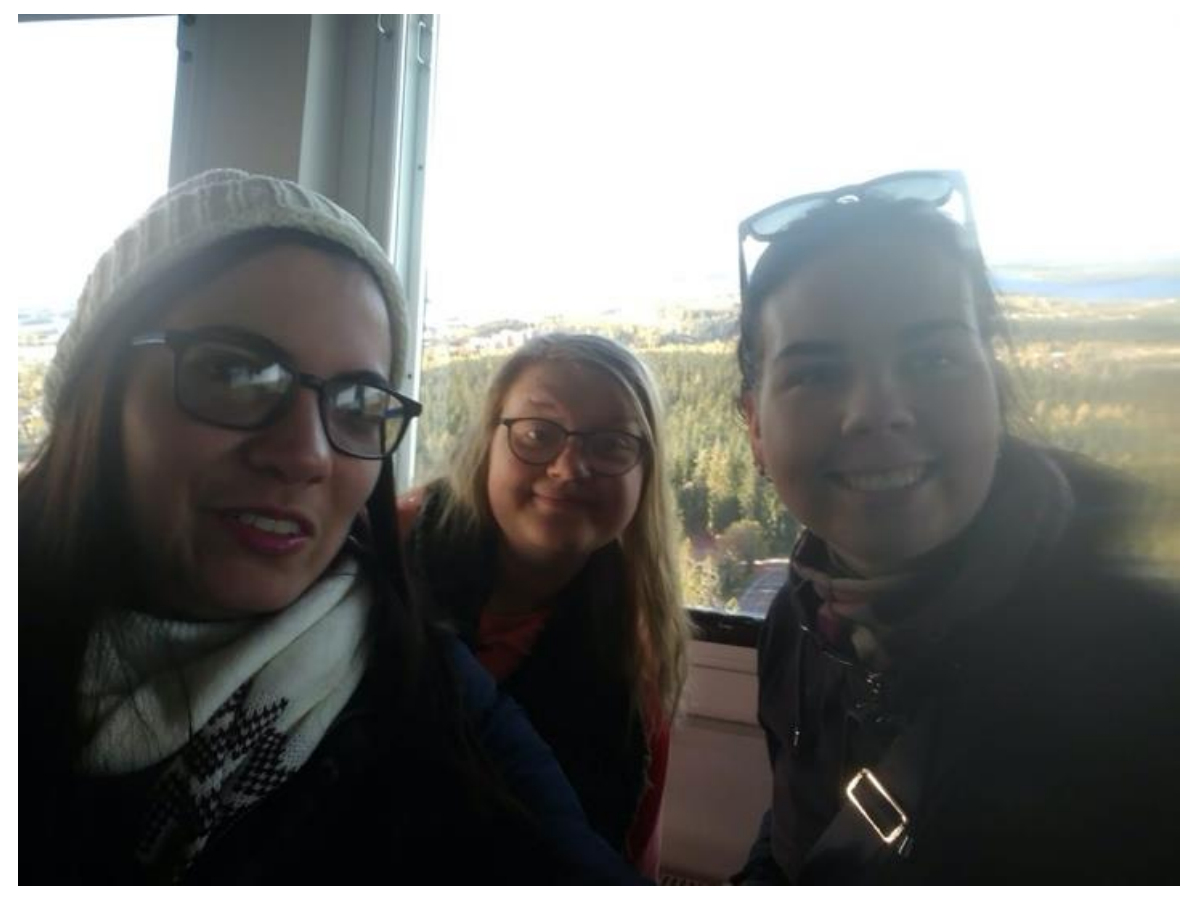

Figure 1 Personal Tutor: Veera Kinnunen. Academic tutor: Outi Vilpponen. (Author's photography.)

These students were very welcoming and made sure the guest students had a good time while staying in Kuopio. As it was mentioned before, they are volunteers, so they take part in these activities without expecting any reward but the cultural exchange they have with the visitors.

\section{The courses taken}

Since mid-August, the two courses were enrolled, fully imparted in English. This was a great advantage since there were no communication problems due to the management of the language. The two professors were very attentive and welcoming as well. Their guidance was very precise and accurate, but at the same time, they were strict and demanding.

\section{Service Design Thinking Professor}

Timo Sirviö, MA, has worked in the field of web service design since 1995. Currently, he works as a senior lecturer of service design thinking, design management, and cultural theory in Savonia School of Design. In addition to 
teaching, he is also designing services and customer experiences across multiple sectors.

Timo is interested in participatory and human-centered design, which means the ability to understand and identify with another person's (the user's) context, emotions, goals, and motivations toward services or products. His mission is to put empathy at the center of all that he does -this creates well-being 5 .

\section{Main project in the course}

As it was mentioned at the beginning of this article, what started this entire internship journey at Savonia UAS was the development of an idea under the frame of design thinking. In this specific case, it consisted on prototyping a bracelet to support the efforts of tour guides. Some parts of the project will be briefly shared in the following sections in order to illustrate a little bit more some areas of the educational system in Savonia UAS.

\section{Challenge description}

In this first section, there is a general explanation about what the project consists on. It includes a rationale and back up information about how the project would come to meet a need of a specific group of users. Additionally, this section expresses the challenges in this design and proposes an innovative idea to create a prototype which will help the tour guides to have better management of their clients. That way, the tour guides will be able to invest their efforts in more meaningful tasks such as finding ways to make tours engaging and meaningful.

\section{Understanding the service}

In this segment, the most important activity is observation. The researcher should observe carefully what the roles of the people involved in the service are. While doing so, the following questions have to be answered:

-What are the staff members doing at the moment of the observation? What kind of roles do they have?

-What are the service moments?

-What are the touchpoints between the customer and the service, including staff, physical space, communication tools, and processes and workflows? Try to use all senses to describe what you observe.

-Who are the users/customers? What are they actually doing? As opposed to what you expected they might do, what routines do they have?

${ }^{5}$ Savonia, «Service Design Thinking Course Invitation for Students» (2018), accessed on September 9, 2018, https://portal.savonia.fi/amk/en 


\section{Interviewing}

In this section, the researcher chooses at least 4 potential users of the service from different backgrounds to be interviewed about their experience as clients; in that way, their variety of opinions can provide more valid results to be analyzed. There are about five relevant questions related to the challenge. The same questions are asked to each one of the subjects selected.

\section{Benchmarking}

With the premise that benchmarking is in this case referred to evaluating how the service works compared to standards, the task is to display in a creative way what the product would look like when being used.

There are several options to elaborate this part. One of them is illustrating the different scenarios in which the product could work. The author of this article chose to elaborate two pages of pictures organized in a collage that combined tour guides in their labor field, and how the use of technology would simplify their job.

\section{Affinity diagram}

This segment of the project consists on using a tool called «Affinity diagram» to organize ideas. The use of this diagram eases the organization of information. In this particular case, it was used to illustrate the different scenarios in which the prototype could be handy and how those settings could relate to each other. This affinity diagram also showed how the different stakeholders are involved to solve the problems tour guides could face. Using different colors and shapes in post-its, the thoughts were organized to clarify patterns of thought which were assembled for an easier understanding and analysis of ideas.

\section{Creating ideas}

This section focuses on Idea generation. The goal was to come up with 100 ideas represented by drawings, symbols, words, sentences, phrases, etc. All the ideas related to the challenge were put together for further analysis. In the beginning, it was difficult to think of the possibility to come up with so many ideas regarding this proposal. However, as the practice took place, concepts kept on coming one after the other, and it was enjoyable to see how far the implications of generating this device could go.

\section{Voting for the best ideas}

The purpose of this section is to filter the ideas by selecting 60 out of the 100 ideas generated in the former part. When filtering the ideas, the topic is narrowed and helps the designer make decisions and establish priorities on what aspects to work on.

\section{Concept creation}

Concept creation also required a lot of thinking, analysis, and creativity, that generated an opportunity to create a scheme in which all the voted ideas from the 
previous section were connected to each other. This brought even more clarity and unification to the ideas, identifying how to proceed with the planning of materializing the prototype this project refers to.

\section{Prototyping}

\section{Personas}

This section required the creation of an imaginary character. In this case, three personas were created. Each persona reflected the target group, the possible users of the service or product being designed. Two possible costumers (tourists) were described as well as a tour guide. The aspects addressed were values, needs, fears, comfort with technology, criteria for success, and wants. Along with those, there is also a demographic description of the persona. This prototyping of personas is usercentered; thus, it helps anticipate their requirements and get feedback on products' design.

\section{Storyboard}

This was also an engaging task in which the designer needs to use a lot of imagination, creativity, and originality. The idea was to draw or create a storyboard that exemplified two scenarios: one in which the prototyped device is used and another one in which the device is not. This would be of great value for evaluating and anticipating possible fails of the service being designed.

\section{Service blueprint}

This segment has the purpose of visualizing the customer's journey on a map. All the services, components and scenarios are explained in cross-functional processes. Every step in the service process was mapped out in this diagram. This technique helps coordination and reduces redundancies; thereafter, it boosts the client's overall experience.

Furthermore, this service blueprint helped see both sides of the parties involved (the employee and the customer); then, there were touchpoints that could be visualized at a wider scope.

\section{Service advertisement}

This was a very functional task, allowing to put into practice creativity design and marketing skills to promote the bracelet proposed in this project.

\section{Reflection}

Finally, at the end of the project, students are asked to write a 3-page reflection on their experience while elaborating every task. This is a very convenient task since it promotes the analysis of what has taken place with a critical perspective which opens room for a lot of improvement. 


\section{Customer and Product Competence in Wellness Professor}

Pauli Verhelä, M.Sc. (econ.) leads the Wellness Team of Savonia to a broad and holistic approach of well-being and wellness. This means that every individual develops in their own way and finds the tools, activities, and material to take care of themselves. Body, Soul, and Mind are the dimensions we believe must be covered in individual wellness.

Verhelä has worked in the development and production of wellness services both in Finland and abroad since the year 1980, when he was planning and managing activity tourism services for supported holidays. His professional history includes touroperating, activity tourism, cultural holidays and of course -wellness tourism. Teaching and developing wellness business education are his passion: wellness concepts and deep customer insight in them are the cornerstones of wellness business ${ }^{6}$.

\section{Main project in the course}

The objective of this project was to design a proposal for a Service Product Development process. This project was supposed to be elaborated in groups; however, because of time constraints and adaptations made in the modality in which it was taken, it was made individually. As suggested by professor Verhelä, the service focused on «Internships for Finnish students in Costa Rica». As every step was carried out, the idea looked more promising after each stage was elaborated. The assignments will be explained briefly as follows.

\section{List of findings}

This consisted of making a list based on a brainstorming of findings related to the topic. The list was not longer than 30 concepts.

After this, the project was divided into three stages.

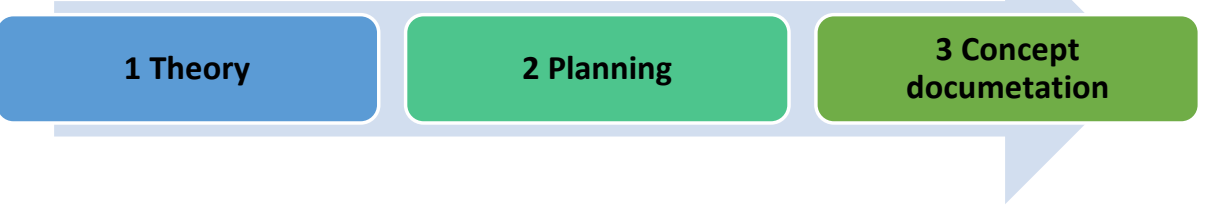

Figure 2 Stages of the project.

\section{Theoretical framework}

This was a compound of literature reference explaining the situation of tourism nowadays in Costa Rica. It also explained what it is like to study tourism at UNED. Besides, it mentioned the way UNED and Savonia University of Applied Science

${ }^{6}$ Savonia University of Applied Sciences, 2019. 
made their first contact and continue to have an alliance today. Finally, this section suggested and backed up why these two institutions should continue making efforts to give opportunities to participate in exchange programs or internships to share their knowledge and culture.

\section{Planning Process}

The following sections were explained in detail:

-Customer Value.

-Define target group / segment.

-Define needs and motivations of the segment based on theory as outcome you get the value, that customer wants to get by using your service.

-Physical Environment.

-Define the place, location and physical features of it.

-Describe also accessibility of the place / location.

\section{Customer Path}

A convenient way to create this section was by using a customer service blueprint. This diagram illustrates all the procedures the internship would need to go through.

\section{Customer service blueprint}

\section{Safety \& Security}

These were the main aspects included in this section:

-Students have to be older than 18 years old.

-Students will need to have a health and accident insurance certificate.

-Students would need to be enrolled in both universities.

-Finnish students do not need a Visa.

-Students will have to follow the rules of their study institutions and in the case of the hotels, they will have to follow their rules as well.

-Students will be staying at homes with families; thus, they will need to obey and follow the commands, guidance, and directions given by their homestay families.

-Students will have to inform if they get out of the space range where they are supposed to be. 


\section{Concept Documentation / Case Documentation}

\section{Product Description / Product Card / Brochure}

The information listed below was included in a brochure to promote the project:

-Producing company.

-Name of the product/package.

-Duration.

-Period, when available, seasons, etc.

-Minimum amount of participants.

-Maximum amount of participants.

-Reservation channels, contact information.

-Price.

-Limitations.

-Accessibility.

-Sales arguments: short sales text.

The project was well accepted and qualified as feasible by professor Verhelä. In conversations with personnel of UNED, they also considered it as an idea that could be materialized. There was a lot of work to do to make it come true, but by going through all the steps these assignments required, it started to make more sense and it seems to be a promising project to carry out.

\section{Other academic activities}

There was a chance to attend several lessons related to tourism, hospitality, and business:

-Multicultural environments, professor Terttu Niskanen.

-Business environments, professor Pentti Makkanen.

-Internationalization processes, Abdelazim Hannoura.

Also, there was an invitation to all the students to attend a Nordic business forum with former United States President Barack Obama that took place in the main auditorium of the school.

Furthermore, a meeting was scheduled with Tina Kousmanen Coordinator of Tourism Projects in Kuopio. She provided fascinating information about the touristic activities in Tahko. 
Another outstanding experience was the chance to have a meeting with professor Anu Mylläri, a Spanish teacher. It was delightful to have a space in her class to give a talk about the Costa Rican culture.

Besides, the International Coordinator (international training \& outgoing students), Jorma Korhonen, gave a very detailed explanation about the study programs in the School of Tourism and Hospitality.

Finally, very kindly, professor Ana Mari Heikkinen granted a chance to participate in two touristic activities. They were «Paintball» and «Canoeing».

As it can be inferred, this internship was a very enriching experience; one that completely changes one's personal and professional life. There was a lot of work and effort to make it come true, but definitely it payed off. One of the best aspects, is that this experience brought a lot of motivation, skills and inspiration to participate in the follow up activities that complemented the success of this brief immersion in the Finnish culture and Design Thinking. These complementary activities will be detailed in the following section.

\section{Follow up activities in 2018-2019}

This section shows activities that were carried out after the internship. Hopefully this will illustrate a glance of how far the projection an internship can go.

\section{Sustainable Tourism Management, article on bulletin}

A space of four pages was granted to share the experience of this internship by the Sustainable Tourism Management Major on the official UNED bulletin. The article was included in the $7^{\text {th }}$ Bulletin in the month of December, 2018. The article can be consulted in the link: https://issuu.com/dinorahcalvoalvarado/docs/bolet_n_7edicion_diciembre_2018

\section{Talk to students from the major}

It was an honor to be invited to share this experience with the students from the Sustainable Tourism Management at UNED on Saturday, February 23 ${ }^{\text {rd }}, 2019$. Hopefully, this talk inspired other students to follow their dreams, work hard, and take advantage of the opportunities available at UNED. The same day, there was also an interview with the School of Human Studies and Science. The video explains briefly what design thinking is and shows the process for this internship in Finland to come true. The link to check this video out is:

https://www.facebook.com/socialesyhumanidades/videos/2337594619818956/?t=21 

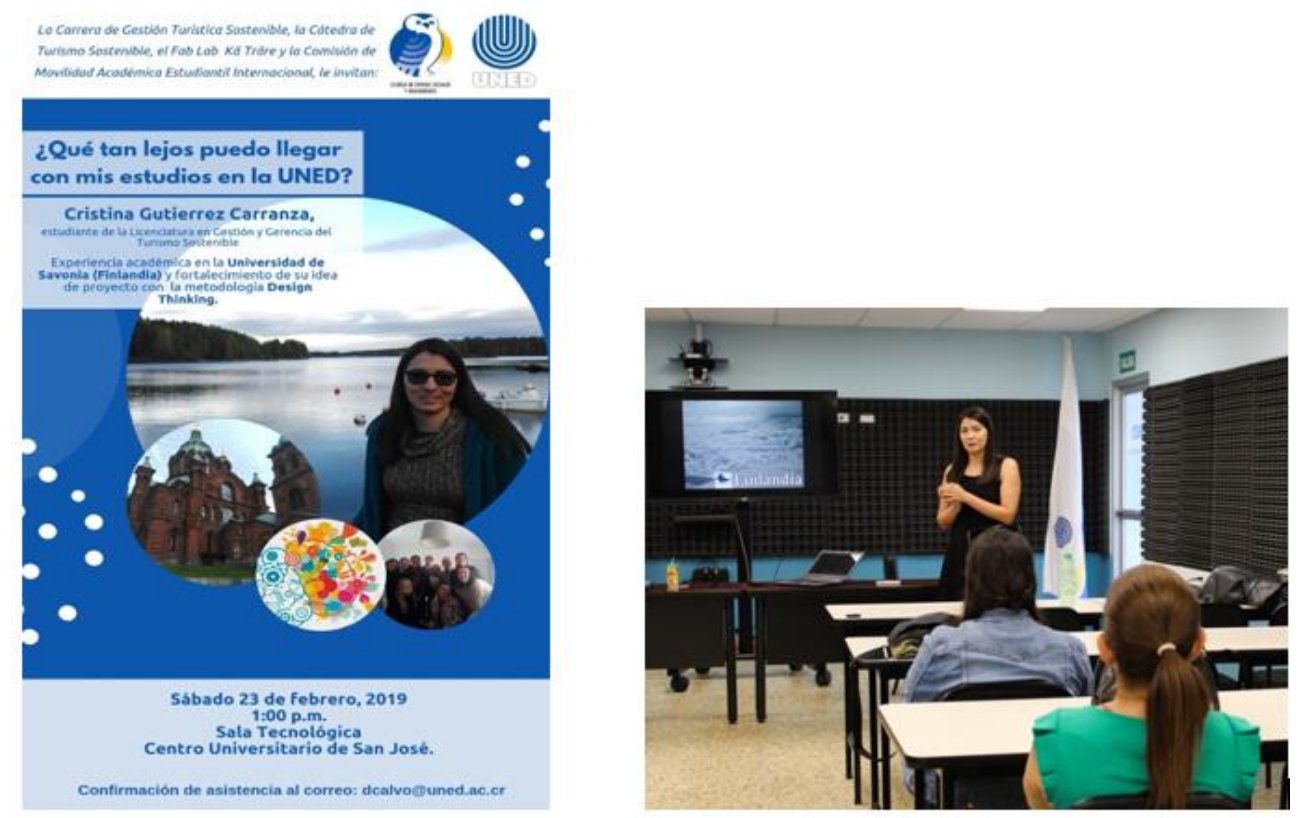

Figure 3 Talk to students. (Author's photography.)

\section{Participation in IV Human Development and Sustainable Tourism Congress}

Among a very busy agenda in this congress, a few minutes were conceded to direct a few words to the participants. This talk focused on eight competences which UNED students acquire as they get exposed to distance studies. In the internship in UAS in Kuopio, Finland, these competences were put into practice and fostered more in the participation. These are very valuable skills for life, for other studies, and for getting incorporated into the labor market. UNED students are lucky to develop them since it makes them stand out of the crowd of typical graduate students they have to compete with once they conclude a major. The competences emphasized in this talk were the ones listed below:

1. Adaptation to IT.

2. Decision making and risk-taking.

3. Persistence and devotion.

4. Speaking other languages.

5. Adaptability.

6. Punctuality and responsibility.

7. Creativity and inventiveness.

8. Time management. 


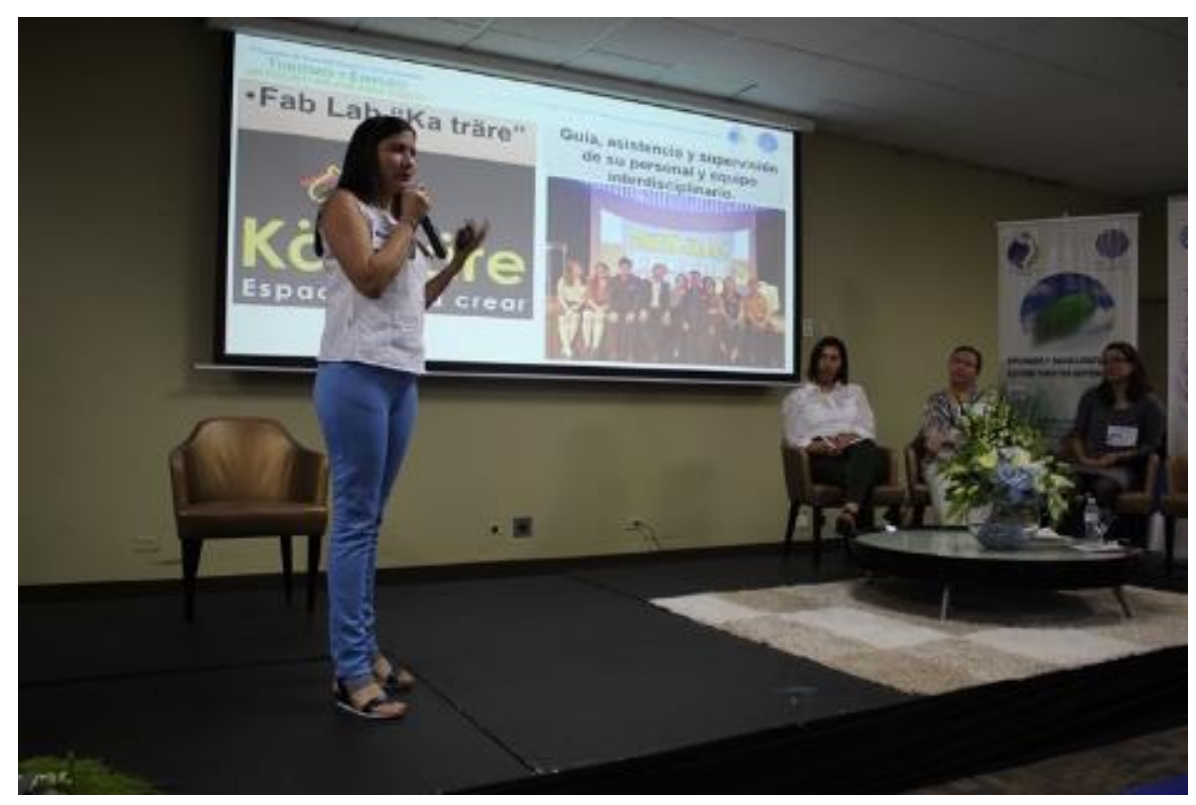

Figure 4 Human Development and Sustainable Tourism Congress. (Author's photography.)

This congress was loaded with very enriching activities like presentations, workshops, conferences, roundtables among others. The purpose of this event was to provide spaces for reflection and analysis of the labor market situation nowadays. These events also referred to how the tourism industry works as a generator of employment and socio-economic development.

\section{Participation in entrepreneurship fair}

The development of the device which inspired this internship in UAS in Kuopio, Finland, also provided the opportunity to be invited to the Fifth Edition of The Entrepreneurship fairs by the Business Administration Chair at UNED. At this event, there was a stand assigned to each one of the projects. The business idea was detailed with the aid of the CANVAS model, a scheme of the prototype, and some needed components. Besides the stand, the project was also explained to the audience and finally, like the rest of the projects, it was defended in front of a group of judges. These people represented different institutions and had a vast background in the field of entrepreneurship. At the end of the event they gave a verdict and awarded the first places in each category. The categories were:

-Social entrepreneurship.

-Technological entrepreneurship.

-Productive linkage.

-Ecological entrepreneurship.

Gladly, the judges voted favorably for this project, demonstrating all the work, time, effort and recourses invested in this project were absolutely worth it. Accordingly, 
this project was granted the first place of its category, a news that was received with great gratitude and pleasure since this is a great asset for the follow-up steps to make the dream of materializing this project to come true.

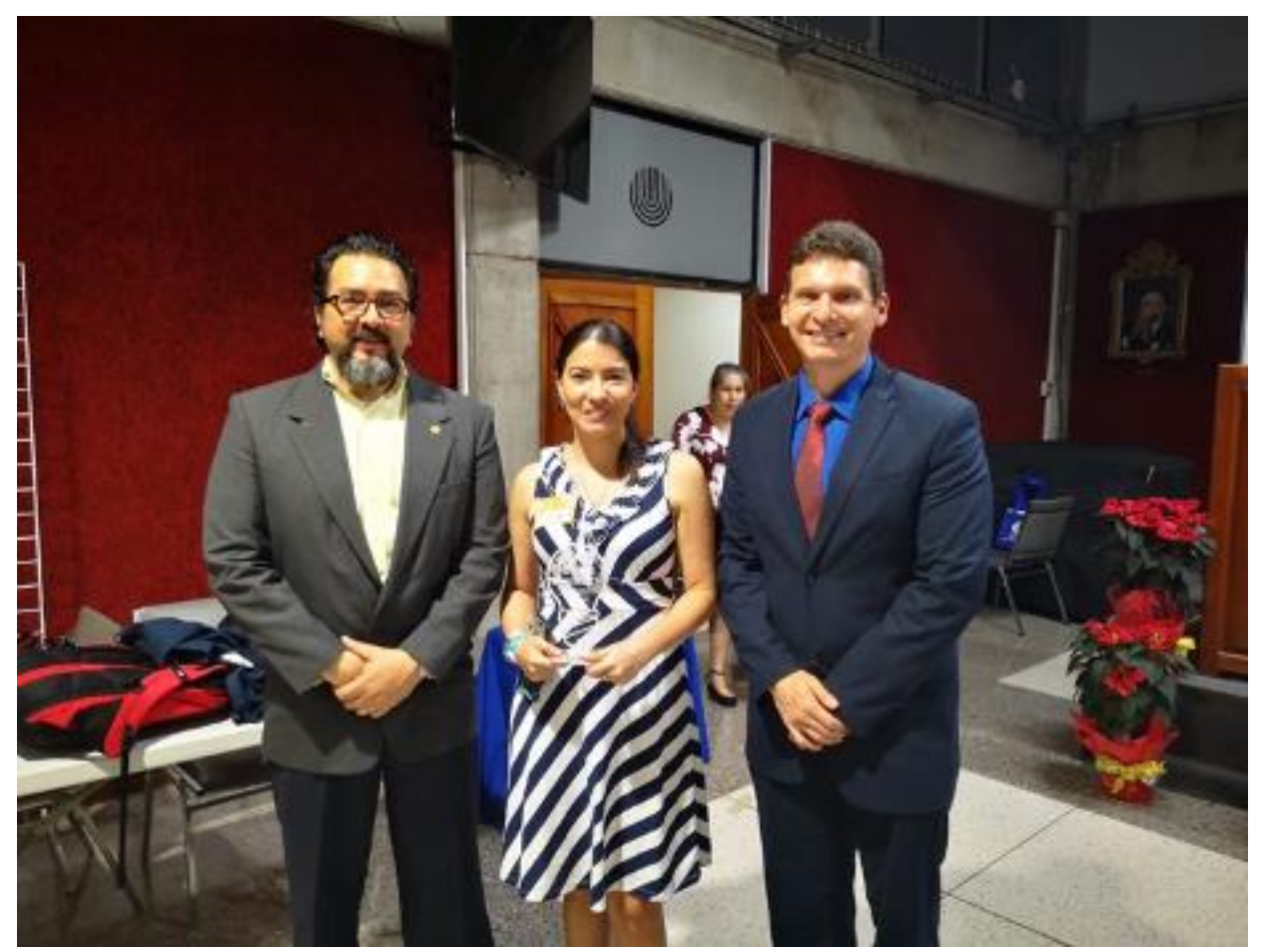

Figure 5 Fifth Edition of The Entrepreneurship fairs. (Author's photography.)

\section{Conclusion}

As it could be illustrated in this article, participating in this internship was a remarkable experience not only professionally but also personally. All in all, even though there were time constraints, this opportunity was an honor and all the possible efforts were made to make the most out of this experience. It was quite encouraging and motivating to see how the decisions made around it and all the events that it generated went on quite successfully. All the personnel from both institutions involved (UNED and UAS) showed a lot of commitment and high-quality professionalism as they contributed for this dream to come true.

Hopefully, by reading this article, many students and readers, in general, will feel motivated and will see examples of how anyone who wants to follow their dreams can make them come true with lots of hard work, passion, and commitment.

One of the best parts of this experience is that it does not have an end. The electronic bracelet is still on the way to being materialized.

The next step related to this technology and design thinking adventure will be to create and materialize the prototype suggested for this device. This is expected to be done along with the Final Graduation Project, which is a requirement to opt for the postgraduate degree at UNED in the mayor of Sustainable Tourism Management. 


\section{Formato de citación según APA}

Gutiérrez-Carranza, C. (2020). How Far Can You Go with Your Studies at UNED?

Revista Espiga, 20 (40), páginas 173-190

\section{Formato de citación según Chicago-Deusto}

Gutiérrez-Carranza, Cristina. «How Far Can You Go with Your Studies at UNED?» Revista Espiga 20, n. ${ }^{\circ} 40$ (julio-diciembre, 2020): páginas 173-190

\section{Works cited}

Fleck, Renee. Stories from Dribble Courside (2019). Accessed on March 22, 2019. https://dribbble.com/stories/2019/03/22/what-is-design-thinking

Gutiérrez, Cristina. «Finlandia. Los sueños sí se pueden hacer realidad, trabaja duro, sueña en grande». Vive turismo (Carrera Gestión Turística Sostenible de la UNED, 2018), 7, 8, 9, 10.

Movilidad Estudiantil, UNED. Accessed on April 09, 2019. https://www.uned.ac.cr/viplan/movilidad-estudiantil

Sandoval, Ana-María. Observatorio de tecnología en educación a distancia (2018). Accessed on March 02, 2019. https://observatoriotecedu.uned.ac.cr/laboratorio-fabricacion-fab-lab-katrare/

Savonia University of Applied Sciences. Savonia UAS (2019). Accessed on January 10, 2019. https://portal.savonia.fi/amk/en/about-savonia

Savonia. «Service Design Thinking Course Invitation for Students» (2018). Accessed on September 9, 2018. https://portal.savonia.fi/amk/en

Savonia University of Applied Sciences. «Wellness Business (2019)». Accessed on January 9, 2019. https://portal.savonia.fi/amk/en/applicants/wellnessbusiness

Stevens, Emily. «Career foundry. What Is Design Thinking? A Comprehensive Beginner's Guide». Accessed on May 16, 2019. https://careerfoundry.com/en/blog/ux-design/what-is-design-thinkingeverything-you-need-to-know-to-get-started/ 